\title{
KECELAKAAN PASIEN AKIBAT KELALAIAN PERAWAT MENJADI ISSU TERKAIT KESELAMATAN PASIEN
}

\author{
Winda Sari Sinaga
}

windasarisng1701@gmail.com

\section{Latar Belakang}

Perawatan merupakan salah satu profesi tenaga kesehatan yang memberikan pelayanan kesehatan langsung baik kepada individu, keluarga dan masyarakat. Pelayanan kesehatan yang diberikan keperawatan adalah dalam bentuk implementasi praktek keperawatan yang ditujukan kepada pasien/klien baik kepada individu, keluarga dan masyarakat dengan tujuan upaya peningkatan kesehatan dan kesejahteraan guna mempertahankan dan memelihara kesehatan serta menyembuhkan dari sakit, dengan kata lain upaya praktek keperawatan berupa promotif, preventif, kuratif dan rehabilitasi.

Dalam praktek keperawatan, perawat secara langsung berhubungan dan berinteraksi kepada pasien maupun keluarga pasien. Perawat menjadi salah satu tenaga kesehatan yang selalu mendampingi pasien dalam waktu yang cukup lama, sehingga sangat berisiko melakukan kelalaian yang dapat menyebabkan pasien cedera. Pada saat perawat berinteraksi dan melakukan tindakan sering kali timbul beberapa hal yang tidak diinginkan baik disengaja maupun tidak disengaja, kondisi demikian inilah sering menimbulkan konflik baik pada diri pelaku dan penerima praktek keperawatan.

Dalam proses pemberian layanan kesehatan dapat terjadi kesalahan berupa kesalahan diagnosis, pengobatan, pencegahan, serta kesalahan sistem lainnya. Berbagai kesalahan tersebut pada akhirnya berpotensi mengakibatkan cedera pada pasien. Hal ini berarti bahwa kesalahan dapat mengakibatkan cedera dan dapat pula tidak mengakibatkan cedera terhadap pasien. Keamanan adalah prinsip yang paling fundamental dalam pemberian pelayanan kesehatan dan sekaligus aspek yang paling kritis dari manajemen kualitas. Keselamatan pasien (patient safety) adalah suatu sistem dimana rumah sakit membuat asuhan pasien lebih aman, mencegah terjadinya cidera yang disebabkan oleh kesalahan akibat melaksanakan suatu tindakan atau tidak mengambil 
tindakan yang seharusnya diambil. Sistem tersebut meliputi pengenalan resiko, identifikasi dan pengelolaan hal yang berhubungan dengan resiko pasien, pelaporan dan analisis insiden, kemampuan belajar dari insiden, tindak lanjut dan implementasi solusi untuk meminimalkan resiko.

Salah satu hal yang dapat menyebabkan pasien cedera dan membahayakan keselamatan pasien ialah kelalaian petugas kesehatan, salah satunya ialah perawat. Kelalaian yang dilakukan perawat adalah salah satu bentuk pelanggaran praktek keperawatan, dimana perawat melakukan kegiatan prakteknya yang seharusnya mereka lakukan pada tingkatannya, lalai atau tidak mereka lakukan. Kelalaian perawat selama memberikan tindakan asuhan keperawatan kepada pasien dapat lihat sebagai bentuk pelanggaran etik ataupun bentuk pelanggaran hukum. Namun dalam praktek pemberian pelayanan kesehatan, seorang perawat harus bertanggung jawab atas segala tindakan yang dilakukan, diberikan kepada pasien. Maka rumah sakit dan perawat dengan sifat profesionalismenya harus bertanggung jawab secara hukum dan sepenuhnya atas kerugian pasien yang disebabkan kelalaian atau tindakan perawat. Profesi keperawatan harus mempunyai standar praktek profesi keperawatan dan aturan lainnya yang didasari oleh ilmu pengetahuan yang dimiliki, guna memberi perlindungan kepada masyarakat. Dengan adanya standar praktek profesi keperawatan inilah dapat dilihat apakah seorang perawat melakukan malpraktek, kelalaian ataupun bentuk pelanggaran praktek keperawatan lainnya. Namun dilain sisi, seorang perawat khususnya perawat pelaksana merupakan garda terdepan dalam menjamin keselamatan pasien terutama pada pasien rawat inap karena perawat pelaksana memiliki kuantitas kontak dengan pasien paling banyak dibandingkan tenaga kesehatan yang lain. Oleh karena itu, pengalaman perawat pelaksana dalam menjamin keselamatan pasien dapat menjadi sesuatu yang menarik untuk digali dan harus terus dikembangkan agar tercipta pelayanan kesehatan yang bermutu.

\section{Metode}

Metode yang digunakan oleh penulis dalam jurnal ini adalah Literature review, dengan cara membaca, menganalisis bahan kajian yang relavan dengan pokok bahasan yaitu kecelakaan pasien akibat kelalaian perawat menjadi issu terkait keselamatan pasien. 
Dimana dengan membaca beberapa jurnal dan bahan kajian terkait lainnya, kemudian menyusun kalimat sendiri yang selanjutnya dituliskan untuk menyelesaikan literature review ini. Bahan kajian yang digunakan yakni berupa textbook, e-book, buku pedoman terkait, tesis dan jurnal online. Adapun jurnal dan referensi yang digunakan pada literature review ini, diterbitkan paling lama tahun 2012, dengan jumlah minimal yaitu 10 referensi.

\section{Hasil}

Dari hasil sumber bacaan yang telah dibandingkan dan dianalisa, didapatkan bahwa yang menjadi penyebab utama terjadinya kecelakaan atau membahayakan keselamatan pasien ialah kelalaian dari seorang perawat. Sikap perawat yang paling sering menjadi penyebab terjadinya kecelakaan kerja yang berpotensi menimbulkan bahaya pada pasien adalah kurangnya penerapan sikap caring, peduli, dan empati kepada pasien. Setiap tindakan yang tidak dilakukan atau tindakan yang dilakukan tetapi tidak sesuai standar keperawatan dilihat sebagai suatu kelalaian perawat yang dapat membahayakan keselamatan pasien.

Sebagian besar sikap dan perilaku caring perawat Indonesia saat ini masih belum terbangun dengan baik. Perawat masih tidak memperhatikan nilai-nilai profesionalisme perawat dan belum mengaplikasikan dalam kegiatan pelayanan keperawatan, yang berpengaruh akan sikap dan perilaku caring perawat dalam memberikan pelayanan kesehatan.

Dalam praktek pelaksanaan pelayanan kesehatan, keluhan terbesar klien dan keluarga tentang perilaku perawat yaitu tidak baik menjadi terbanyak kedua dalam laporan atau survey kepuasan pasien terhadap pelayanan rumah sakit. Perilaku perawat yaitu tidak ramah, judes, dan bersikap kasar dalam melayani klien perawat dan seringkali tidak perduli dan meremehkan akan keluhan dan laporan-laporan kecil dari pasien atau keluarga pasien. Kejadian-kejadian inilah yang sering kali menjadi kejadian yang berpotensi menimbulkan bahaya pada pasien.

Dalam sumber jurnal lain mendukung hasil penelitian sebelumnya, bahwa adanya pengaruh sikap perawat peduli serta bertanggung jawab dalam memenuhi pemenuhan kebutuhan klien menjadi aspek yang mendukung rendahnya nilai tingkat kecelakaan dan cedera pasien dirumah sakit. Esensi caring juga ditunjukkan dengan sikap perawat yang peduli terhadap kebutuhan dan kesejahteraan klien serta keluarganya. Pada penelitian digambarkan dengan 
perawat memiliki respons positif dalam menerima, dan berperilaku caring kepada orang lain, cepat melayani klien, peduli dengan keadaan dan penderitaan klien, mempunyai integritas pribadi yang kuat.

Pada jurnal lainnya menjelaskan mengenai dasar hukum perundang-undangan praktek keperawatan yang menyangkut masalah kelalaian. Kelalaian merupakan tindakan yang bersifat tidak disengaja dan kelalaian tidak sama dengan malpraktek. Kelalaian perawat merupakan salah satu bagian dari Adverse Event atau Kejadian Tidak Diharapkan (KTD). Dimana KTD merupakan suatu kejadian yang mengakibatkan cedera yang tidak diharapkan pada pasien karena suatu tindakan (commission) atau tidak mengambil tindakan yang seharusnya diambil (omission), dan bukan karena "underlying disease" atau kondisi pasien. Dan sikap perawat yang menyebabkan terjadinya kecelakaan yang dapat membahayakan pasien merupakan kondisi potensial cedera, atau kondisi yang sangat berpotensi untuk menimbukan cedera.

Pada hasil penelitian didapatkan bahwa dasar hukum mengenai kejadian atau tindakan kelalaian perawat dirumah sakit merupakan tanggung jawab rumah sakit. Rumah sakit harus bertanggung jawab secara hukum terhadap semua kerugian yang ditimbulkan atas kelalaian yang dilakukan tenaga kesehatan di rumah sakit dan apabila kesalahan atau kelalaian disebabkan oleh si korban maka ganti rugi tidak akan diberikan.

\section{Pembahasan}

Keselamatan pasien di Rumah sakit merupakan unsur penting guna meningkatkan kualitas pelayanan kesehatan khususnya di rumah sakit sebagai bentuk implementasi dan refleksi sentuhan hasil kompetensi tenaga kesehatan, ketersediaan sarana dan prasarana layanan serta sistem manajeman dan administrasi dalam siklus pelayanan terhadap pasien. Keselamatan dan keamanan merupakan kebutuhan dasar manusia. Keselamatan pasien merupakan prioritas dalam pelayanan di rumah sakit dan sudah menjadi tuntutan kebutuhan dalam pelayanan kesehatan. Keselamatan mencakup pasien penghindaran, pencegahan dan perbaikan dari hasil tindakan yang buruk atau injuri yang berasal dari proses perawatan kesehatan. Keselamatan pasien terutama berkaitan dengan penghindaran, pencegahan dan perbaikan hasil buruk atau injuri yang berasal dari 
perawatan kesehatan itu sendiri. Ini harus membahas kejadian yang mencakup rangkaian kesalahan dan penyimpangan terhadap kecelakaan.

Kejadian kecelakaan akibat kelalaian atau kesalahan dari pihak tenaga kesehatan dengan keadaan tidak sengaja, dan bersifat not intentional. Menurut Sampurno (2005), kelalaian adalah segala tindakan yang dilakukan dan dapat melanggar standar sehingga mengakibatkan cidera/kerugian orang lain. Sedangkan menurut Amir dan Hanafiah (1998) yang dimaksud dengan kelalaian adalah sikap kurang hati-hati, yaitu tidak melakukan apa yang seseorang dengan sikap hati-hati melakukannya dengan wajar, atau sebaliknya melakukan apa yang seseorang dengan sikap hati-hati tidak akan melakukannya dalam situasi tersebut. Kelalaian atau Negligence, dapat berupa Omission yaitu kelalaian untuk melakukan sesuatu yang seharusnya dilakukan atau Commission yaitu melakukan sesuatu secara tidak hati-hati. Kelalaian dalam pemberian tidakan tidak sama dengan malpraktek, tetapi kelalaian termasuk dalam pemahaman malpraktik, tetapi tidak selalu ada unsur kelalaian dalam malpraktek. Tidak semua kecelakaan kerja dapat dikategorikan sebagai kelalaian. Tindakan atau sikap tenaga kesehatan dianggap lalai, apabila terkandung keempat unsur yang bersifat not intentional. Yang pertama yaitu duty atau kewajiban. Duty merupakan kewajiban tenaga kesehatan untuk melakukan tindakan atau untuk tidak melakukan tindakan tertentu terhadap pasien tertentu pada situasi dan kondisi tertentu. Yang kedua yaitu dereliction of the duty atau penyimpanagan kewajiban, dimana perawat secara utuh melakukan penyimpangan kewajiban tanpa alasan tertentu atau karena kurangnya pengetahuan dan tidak bagian kompotensi perawat. Yang ketiga dalah damage atau kerugian, yaitu segala sesuatu yang dirasakan oleh pasien sebagai kerugian akibat dari layanan kesehatan yang diberikan oleh pemberi pelayanan. Yang keempat yaitu direct cause relationship atau hubungan sebab akibat yang nyata, yang mana dalam hal ini harus terdapat hubungan sebab akibat antara penyimpangan kewajiban dengan kerugian yang setidaknya menurunkan Proximate cause.

Kelalaian dapat disebut sebagai bentuk pelanggaran etik ataupun bentuk pelanggaran hukum, tergantung bagaimana masalah kelalaian itu dapat timbul, maka yang penting adalah bagaimana menyelesaikan masalah kelalaian ini dengan memperhatikan dari berbagai sudut pandang, baik etik, hukum, manusianya baik yang memberikan layanan maupun penerima layanan. 
Bagaimana bentuk pelanggaran dari kelalaian yang dilakukan dapat dikategorikan menjadi malfeasance, misfeasance, dan nonfeasance. Peningkatan kualitas praktek keperawatan, adanya standar praktek keperawatan dan juga meningkatkan kualitas sumber daya manusia keperawatan adalah hal penting. Liabilitas adalah tanggungan yang dimiliki oleh seseorang terhadap setiap tindakan atau kegagalan melakukan tindakan. Perawat profesional, seperti halnya tenaga kesehatan lain mempunyai tanggung jawab terhadap setiap bahaya yang timbulkan dari kesalahan tindakannya. Tanggungan yang dibebankan perawat dapat berasal dari kesalahan yang dilakukan oleh perawat baik berupa tindakan kriminal kecerobohan dan kelalaian. Seperti telah didefinisikan diatas bahwa kelalaian merupakan kegagalan melakukan sesuatu yang oleh orang lain dengan klasifikasi yang sama, seharusnya dapat dilakukan dalam situasi yang sama, hal ini merupakan masalah hukum yang paling lazim terjadi dalam keperawatan. Terjadi akibat kegagalan menerapkan pengetahuan dalam praktek antara lain disebabkan kurang pengetahuan. Dan dampak kelalaian ini dapat merugikan pasien. Sedangkan akuntabilitas adalah konsep yang sangat penting dalam praktik keperawatan. Akuntabilitas mengandung arti dapat mempertaggung jawabkan suatu tindakan yang dilakukan dan dapat menerima konsekuensi dari tindakan tersebut.

Untuk kejadian kelalaian kategori malfeasance, berkaitan dengan tindakan yang melanggar hukum atau tidak tepat/layak. Kejadian yang tercakup didalamnnya yaitu melakukan tindakan keperawatan tanpa indikasi yang memadai/tepat. Tanggung jawab hukum pidana profesi perawat jelas merupakan tanggung jawab perorangan atas perbuatan pelanggaran hukum pidana yang dilakukannya. Jenis pidana yang mungkin dituntutkan kepada perawat adalah pidana kelalaian yang mengakibatkan luka (pasal 360 KUHP), atau luka berat atau mati (pasal 359 KUHP), yang dikualifikasikan dengan pemberatan ancaman pidananya bila dilakukan dalam rangka melakukan pekerjaannya (pasal 361 KUHP). Sedangkan pidana lain yang bukan kelalaian yang mungkin dituntutkan adalah pembuatan keterangan palsu (pasal 267-268 KUHP). Didalam setting Rumah Sakit, pidana kelalaian yang dapat dituntutkan kepada profesi perawat dapat berupa kelalaian dalam melakukan asuhan keperawatan maupun kelalaian dalam melakukan tindakan medis sebagai pelaksana delegasi tindakan medis. Kelalaian dapat berupa kelalaian dalam mencegah kecelakaan di Rumah Sakit (jatuh), kelalaian dalam mencegah terjadinya decubitus atau pencegahan infeksi, kelalaian dalam melakukan pemantauan keadaan pasien, kelalaian dalam merespon suatu kedaruratan, dan bentuk kelalaian lainnya yang juga dapat terjadi pada pelayanan profesi perorangan. 
Berkaitan dengan penyebab terjadinya kejadian yang membahayakan pasien akibat kelalaian perawat juga dipengaruhi sikap dan perilaku perawat yang tidak caring, peduli, dan empati kepada pasien. Sikap perawat yang seharusnya menjadi dasar memberikan pelayanan kesehatan yaitu Sikap peduli terhadap pemenuhan kebutuhan klien Perawat jika mendengar bel berbunyi segera mendatangi klien dengan tetap melakukan komunikasi yang ramah. Sikap peduli bisa diamati dengan kegiatan perawat sesegera mungkin mendatangi klien dan menyatakan kesediaan untuk membantu klien.

Sikap perawat yang bertanggung jawab menunjukkan bahwa perawat pelaksana bertanggung jawab dalam memenuhi inti nilai moral perawat dalam melaksanakan perannya. Perilaku caring merupakan inti nilai-nilai moral keperawatan, bahwa inti moral dan etik keperawatan adalah tanggung jawab dalam memberikan pelayanan keperawatan kepada klien, perawat mempunyai respons terhadap apa yang dilakukannya apakah baik atau tidak baik secara moral. Peneliti berpendapat bahwa tanggung jawab dalam melaksanakan tugas akan terlihat dari seorang perawat profesional dengan menampilkan perilaku caring dalam seluruh aktivitas pelayanan keperawatan. Inti rasa tanggung jawab itu adalah kepekaan perawat terhadap penderitaan klien, keluarga, dan peduli dengan situasi serta kondisi lingkungan dimana klien dirawat, merupakan perilaku caring perawat. Perilaku caring merupakan bentuk tanggung jawab perawat terhadap perannya. Perilaku lainya yang menajadi gambaran dalam memberikan pelayanan kesehatan adalah bersikap ramah dalam melayani klien, sikap tenang dan sabar dalam melayani klien, selalu siap sedia memenuhi kebutuhan klien, memberi motivasi kepada klien dan sikap empati terhadap klien.

Dari hasil penelitian sumber bacaan menunjukan perawat yang memiliki sikap empati terhadap pasien secara tulus tergambar dari pernyataan perawat yang ikut merasakan ketika klien mengalami rasa sakit, sesak nafas, dan turut empati dengan kesedihan keluarga yang berduka karena klien sebagai anggota keluarganya meninggal di rumah sakit. Hasil observasi menunjukkan perawat mengucapkan bela sungkawa, menepuk punggung keluarga yang berduka, dan mengelus tangan klien yang kesakitan. Sikap empati ini merupakan indikator perilaku caring perawat pelaksana. Karakteristik pribadi perawat yang khusus dan sifat kepribadian seperti : emosi perawat, sikap, empati, dan respon organisasi dan Karakteristik pribadi seperti kata hati, relijius, kepercayaan, filosofi, komitmen, respons, dan altruisme berkontribusi terhadap perilaku caring 
perawat. Perawat yang mempunyai karakteristik demikian akan lebih banyak sabar dan empati serta bertanggungjawab dalam melayani klien.

Sikap perawat yang tidak baik dapat menjadi salah satu penyebab terjadinya kelalaian dan dapat membahayakan keselamatan pasien. Kejadian-kejadian inilah yang sering kali menjadi kejadian yang berpotensi menimbulkan bahaya pada pasien. Beberapa situasi yang berpotensial menimbulkan tindakan kelalaian dalam keperawatan diantaranya yaitu :

1). Kesalahan pemberian obat.

Bentuk kelalaian yang paling sering terjadi, hal ini dikarenakan begitu banyaknya jumlah obat yang beredar metode pemberian yang bervariasi. Kelalaian yang sering terjadi, diantaranya kegagalan membaca label obat, kesalahan menghitung dosis obat, kesalahan mempersiapkan konsentrasi, atau kesalahan rute pemberian. Beberapa kesalahan tersebut akan menimbulkan akibat yang fatal, bahkan menimbulkan kematian.

2).Mengabaikan Keluhan Pasien

Perilaku perawat yaitu tidak ramah, judes, dan bersikap kasar dalam melayani klien perawat dan seringkali tidak perduli dan meremehkan akan keluhan dan laporan-laporan kecil dari pasien atau keluarga pasien. Padahal dapat saja keluhan pasien menjadi data yang dapat dipergunakan dalam menentukan masalah pasien dengan tepat.

\section{3). Kesalahan Mengidentifikasi Masalah Klien}

Pada kondisi atau kemunungkinan situasi rumah sakit yang sibuk, menyebabkan kondisi pasien tidak dapat secara rinci diperhatikan.

4). Kelalaian terhadap keamanan dan keselamatan Pasien

Pada sumber bacaan dijelaskan sering ditemukan kejadian pasien jatuh dari tempat tidur karna perawat lalai dan tidak memasang kembali bedside rail tempat tidur pasien.

\section{Penutup}

Perawat berperan penting dalam setiap tindakan yang berhubungan dengan Asuhan Keperawatan yang akan diberikan kepada pasien. Perawat menjadi salah satu tenaga kesehatan 
yang harus menjamin keselamatan pasien selama dirawat di rumah sakit. Untuk itu perawat harus mampu bersikap profesional, dan mampu melakukan tindakan keperawatan secara terampil dan harus bertanggung jawab dan bertanggung gugat atas segala tindakan yang dilakukannya. Kelalaian perawat dalam tindakannya harus di klarifikasi terlebih dahulu apakah merupakan kelalaian atau sudah masuk dalam tahapan malpraktik, setiap rumah sakit memiliki peraturan tersendiri mengenai tanggung jawab atas kejadian kecelakaan yang dapat menyebabkan bahaya bagi pasien akibat dari kelalaian perawat. Namun dasar hukum mengenai kelalaian tindakan keperawatan yaitu rumah sakit bertanggung jawab secara hukum terhadap semua kerugian yang ditimbulkan atas kelalaian yang dilakukan tenaga kesehatan di Rumah Sakit. Dalam praktik pelayanan kesehatan di Rumah Sakit penting Seorang perawat untuk menerapkan dan melakukan sikap carinh terhadap seluruh klien atau pasien yang berada di rumah sakit. Dengan perawat mampu bersikap caring terhadap seluruh pasien rawat yang dirawat di rumah sakit akan sangat menurunkan kejadian kecelakaan akibat dari kelalaian perawat.

\section{Daftar Pustaka}

Firawati., Pabuty,Aumas., Putra,Setia,Abdi. 2012. Pelaksanaan Program Keselamatan Pasien di RSUD Solok. Jurnal Kesehatan Masyarakat. 6(2).

Tukatman, dkk. 2015. ANALISIS KESELAMATAN DAN KESEHATAN KERJA PERAWAT DALAM PENANGANAN PASIEN DI RUMAH SAKIT BENYAMIN GULUH KABUPATEN KOLAKA. Jurnal Ners. 10(2) : 343-347.

P. I. Silvia Maria, dkk. 2015. KEJADIAN KECELAKAAN KERJA PERAWAT BERDASARKAN TINDAKAN TIDAK AMAN. Jurnal Care. 3( 2) : 9-17.

Harus, Dece, Bernadeta., Sutriningsih, Ani. 2015. Pengetahuan Perawat tentang Keselamatan Pasien dengan Pelaksanaan Prosedur Keselamatan Pasien Rumah Sakit (KPRS) di Rumah Sakit Panti Waluya Sawahan Malang. Jurnal Care. 3(1).

Dedi, Blacius, dkk. 2018. PERILAKU CARING PERAWAT PELAKSANA DI SEBUAH. Jurnal Keperawatan Indonesia. 12(1) : 40-46. 
Ernawati, N., \& Nurlelawati, E. 2017. Faktor-Faktor Yang Berhubungan Dengan Pelaksanaan Penerapan K3 Pada Tenaga Kesehatan di RSIA Permata Sarana Husada Periode Februari 2015. Jurnal Akademi Keperawatan Husada Karya Jaya. 3 (1) : 12-18.

Siregar Rospita A.. 2016. HUBUNGAN PERAWAT DAN PASIEN: IMPLEMENTASI STANDAR KESELAMATAN PASIEN. Jurnal Hukum tora. 2 (1).

Isnaini, Nur Mahya, dkk. 2014. PENGALAMAN PERAWAT PELAKSANA DALAM MENERAPKAN KESELAMATAN PASIEN. Jurnal Managemen Keperawatan . 2 (1) : 30-37.

Fitriana, Y., \& Pratiwi, K.. 2018. Pelaksanaan Patient Safety di Rumah Sakit Umum Daerah dan rumah sakit umum swasta bantul berdasarkan ketentuan undang-undang nomor 44 tahiun 2009 tentang rumah sakit. Jurnal Kebidanan. 7(1): 28-39.

Simamora, R. H., \& Nurmaini, C. T. S. (2019). Knowledge of Nurses about Prevention of Patient Fall Risk in Inpatient Room of Private Hospital in Medan. Indian Journal of Public Health Research \& Development, 10(10), 759-763.

Mudayana, Ahid Ahmad. 2014. Peran Aspek Etika Tenaga Medis dalam Penerapan Budaya Keselamatan Pasien di Rumah Sakit. Jurnal Majalah Kedokteran Andalas. 37(1). 